\title{
Effects of different regimens of PGF2a treatment during postpartum on reproductive performance in dairy cows
}

\section{Efeito de diferentes regimes de tratamento pós-parto com PGF2a sobre o desempenho reprodutivo de vacas leiteiras}

\author{
Reza Narenji SANI ${ }^{1}$; Hamid Reza MOHAMMADI ${ }^{1}$; Ali MAHDAVI ${ }^{2}$; Hosein DADASHPOUR ${ }^{1}$ \\ ${ }^{1}$ Semnan University, Faculty of Veterinary Medicine, Department of Clinical Sciences, Semnan - Iran \\ ${ }^{2}$ Semnan University, Faculty of Veterinary Medicine, Department of Animal Sciences, Semnan - Iran
}

\begin{abstract}
The aim of this study was to evaluate the effects of early postpartum PGF2 $\alpha$ treatment on reproductive performance in dairy cows synchronized with targeted breeding and natural mating after voluntary waiting period. In this experiment ,120 cows were assigned to three groups irrespective of presence or absence of luteal tissue. Cows in PG14 group were treated with PGF2 $\alpha$ from day 14 postpartum, cows in PG-28 group were treated with PGF2 $\alpha$ from day 28 postpartum and cows in PG-42 group were not treated with PGF2 $\alpha$ until the end of voluntary waiting period (d 42). After day 42 postpartum, cows in three groups were treated with PGF2 $\alpha$ within 14-day intervals until natural mating after voluntary waiting period. Recorded reproductive parameters included days to first heat, days to first mating, days open, service per conception, conception rate, percentage of repeat breeder animals and pregnancy loss. Early PGF2 $\alpha$ treatment from day 14 postpartum significantly decreased days to first estrus $(34.9 \pm 0.74, \mathrm{P}<$ $0.003)$, days to first mating $(62.35 \pm 1.53, \mathrm{P}<0.04)$, days open $(117.23 \pm 3.1, \mathrm{P}<0.001)$ and service per conception $(1.9 \pm 0.09, \mathrm{P}<0.02)$; and $\mathrm{PG}-14$ group presented increased conception rate $(52.5 \%, \mathrm{P}<0.05)$. The proportion of repeat breeder syndrome tended to be affected by treatment with PGF2 $\alpha$ from day 14 postpartum. In conclusion, treatment of cows with PGF2 $\alpha$ from day 14 postpartum improved reproductive performance.
\end{abstract}

Keywords: PGF2 $\alpha$. Postpartum. Targeted breeding. Natural mating.

\section{Resumo}

O objetivo do presente trabalho foi avaliar os efeitos do tratamento pós-parto precoce com PGF2 $\alpha$ sobre o desempenho reprodutivo de vacas leiteiras sincronizadas para reprodução controlada por monta natural após o período de espera voluntário. Neste experimento, 120 vacas foram distribuídas em três grupos independentes da presença ou ausência de corpo lúteo. Vacas no grupo PG-14 foram tratadas com PGF2 $\alpha$ a partir do $14^{\circ}$ dia pósparto, vacas do grupo PG-28 foram tratadas com PGF2 $\alpha$ a partir do $28^{\circ}$ dia pós-parto e as vacas do grupo PG-42 não foram tratadas com PGF2 $\alpha$ até o final do período de espera voluntário (d42). Após o $42^{\circ}$ dia pós-parto as vacas dos três grupos foram tratadas com PGF2 $\alpha$ com intervalos de 14 dias até a monta natural após o período de espera voluntário. Os registros dos parâmetros reprodutivos incluíram: dias para o primeiro estro, dias para a primeira cobertura, dias em aberto, serviços por concepção, taxa de concepção, percentagem de animais repetidores de cios e as perdas de gestações. O tratamento precoce com PGF2 $\alpha$, a partir do $14^{\circ}$ dia pós-parto reduziu significativamente os dias para o primeiro estro $(34,9 \pm 0,74, \mathrm{P}<0,003)$, dias para a primeira cobertura $(62,35 \pm 1,53, \mathrm{P}<0,04)$, dias em aberto $(117,23 \pm 3,1, \mathrm{P}<0,001)$ e o número de serviços por concepção $(1,9 \pm 0,009, \mathrm{P}<0,02)$; e o grupo PG-14 apresentou um acréscimo na taxa de concepção $(52,5 \%, \mathrm{P}<0,05)$. A proporção da síndrome de vacas repetidoras de cios tendeu a ser afetada pelo tratamento com PGF2 $\alpha$ a partir do $14^{\circ}$ dia pós-parto. A conclusão obtida foi que o tratamento das vacas com PGF2 $\alpha$ a partir do $14^{\circ}$ dia pós-parto melhorou o desempenho reprodutivo dos animais. Palavras-chave: PGF2 $\alpha$. Pós-parto. Reprodução controlada. Monta natural. 
Correspondence to:

Reza Narenji Sani

Semnan University, Faculty of Veterinary Medicine,

Department of Clinical Sciences

PO Box 35131-19111, Semnan, Iran

e-mail: rezasani_vet@profs.semnan.ac.ir

Received: 21/11/2015

Approved: 03/10/2016

\section{Introduction}

The events that must be completed after parturition before a cow is likely to conceive again are uterine involution, regeneration of the endometrium, elimination of bacterial contamination from the uterus, and the return of ovarian cyclical activity (SHELDON et al., 2008). Favorable uterine involution is very important for the next reproductive cycle of postpartum cows, and influences subsequent fertility (THATCHER et al., 2006). Most postpartum dairy cows are invaded by opportunistic and pathogenic bacteria within the first 21 days postpartum (THATCHER et al., 2006; SHELDON et al., 2008). In most instances, cows eliminate these bacteria from the uterus by approximately three weeks postpartum; however, some do not, and the presence of these bacteria predisposes these cows to reduced reproductive performance (HENDRICKS et al., 2006).

The early postpartum uterus produces large amounts of the F-series prostaglandins (GUILBAULT et al., 1984), as reflected by high peripheral concentrations of 13, 14-dihydro-15-ketoprostaglandin F-metabolite (PGFM). The concentration of PGFM increases in plasma prior to parturition, due to the release of prostaglandin F2 alpha (PGF2 $\alpha$ ). Secretion of PGF2 $\alpha$ leads, in most cows, to a decrease in progesterone 1-2 days before parturition and to the final regression of the CL. A major increase in PGFM in blood plasma occurs 1-4 days postpartum, followed by a slow decrease to a basal level by day 15 . This decrease has been found to be associated with uterine regression and a reduction in the rate of involution (EDQVIST et al., 1978).
There are conflicting reports on the effectiveness of exogenous PGF2 $\alpha$ to increase the rate of uterine involution, cause evacuation of bacterial contamination from the uterus, and subsequently improve conception rate (YOUNG et al., 1984; ETHERINGTON et al., 1988; ARCHBALD et al., 1990; RISCO et al., 1994). These reports examined the use of PGF $2 \alpha$ on either one or two occasions between 12 and 40 days postpartum, without regard to the presence of a functional corpus luteum (CL). After PGF2 $\alpha$ administration 25-32 days postpartum, improved fertility has been observed in cattle (PANKOWSKI et al., 1995). Peters (1989) concluded that enhancement of the reproductive performance of cows treated with PGF2 $\alpha$ after parturition is not due to a direct effect on pituitary ovarian function (PETERS, 1989). The presence of a CL did not influence the outcome of prostaglandin treatment (GLANVILL; DOBSON, 1991) and the effects of PGF2 $\alpha$ administered at day 26 postpartum on the uterine involution and reproductive performance is independent of progesterone level at the time of treatment (MCCLARY et al., 1989; BONNETT et al., 1990; RISCO et al., 1994).

It was reported that exogenous PGF2a would be more consistently effective in increasing motility and evacuation of bacterial contamination of the postpartum uterus if it was administered when there is a CL in the ovary (NAKAO et al., 1997; HIRSBRUNNER et al., 2003). Some research has shown no improvement in pregnancy rates (MORTIMER et al., 1984), but other workers have shown significant improvements in the pregnancy rates of cows treated 14-28 days postpartum with a single injection of PGF2a (YOUNG et al., 1984). Benmrad and Stevenson (1986) reported that postpartum administration of prostaglandin F2a reduces the number of services required per conception (BENMRAD; STEVENSON, 1986).

In PGF2 $\alpha$-based breeding programs, often referred to as Target Breeding or Monday Morning Breeding Programs, groups of cows are injected with PGF2 $\alpha$ as 
they reach the voluntary waiting period (VWP) and are bred to detected estrus for the next three to five days (DEJARNETT, 2015). Cows not bred after the first injection are re-treated with PGF2 $\alpha 14$ days later and observed for estrus for another five days. A set-up PGF2 $\alpha$ injection 14 days before the first breeding injection will help to improve estrous response at this first breeding opportunity. The hypothesis of the present study was that repeated administration of PGF2 $\alpha$ in the immediate postpartum period would increase the reproductive performance after natural mating in postpartum dairy cows synchronized with targeted breeding. Therefore, we aimed to determine the effect of administration of PGF $2 \alpha$ in the immediate postpartum period on reproductive performance in dairy cows synchronized with targeted breeding and naturally mated at estrus after a VWP.

\section{Materials and methods}

\section{Animals and study farm}

The study was conducted from March 2014 to March 2015 on 138 Holstein cows from a commercial dairy herd in suburb of Semnan, Iran. Cows were no seasonal, year-round calvers and milked thrice daily. Cows were housed in free-stall barns and fed a total mixed ration (TMR) three times daily. The TMR was formulated to meet or exceed requirements for lactation. Cows were blocked according to parity and milk production. The VWP was 42 days, and cows detected in estrus were naturally mated. Heat detection was done by visual observation.

\section{Study design}

Each animal in each block was randomly assigned to one of the following three groups. PGF2 $\alpha$ treatment in PG-14 group $(\mathrm{n}=40)$ started on $\mathrm{d} 14$ postpartum, in PG-28 group $(\mathrm{n}=40)$ started on $\mathrm{d} 28$ postpartum and in PG-42 $(\mathrm{n}=40)$ cows only received PGF2 $\alpha$ treatment after the end of VWP (42d). Cows in three groups were treated with PGF2 $\alpha$ every 14 days starting on day 14,28 or 42 and continued until natural mating after VWP. Intramuscular injection of $5 \mathrm{~mL}$ prostaglandin F2a (Lutalyse; Pfizer Animal Health, New York, NY, USA, containing 25mg dinoprost) was administered to each cow.

Animals were excluded or withdrawn from this experiment for any of the following reasons: failure to complete the treatment scheme, animals with retained fetal membrane or dystocia which later experienced metritis and were treated with systemic antibiotics and/or PGF2 $\alpha$, animals that underwent surgery (correction of displaced abomasum), animals placed in the hospital barn that received systemic antibiotic therapy during the study period, animals assigned as controls (PG-42) that were treated with PGF2 $\alpha$ during VWP and animals culled from the herd or died during the study period.

\section{Mating, pregnancy diagnosis, pregnancy loss, and reproductive performance}

All cows were mated after VWP and examined for pregnancy by ultrasonography on days $32 \pm 3$ after mating. Detection of an embryonic vesicle with a viable embryo in which heartbeat was visualized, was used as an indicator of pregnancy. Pregnant cows were palpated again per rectum 30 days later (62 \pm 3 after mating) for confirmation of pregnancy. Recorded reproductive parameters were days to first estrus, days to first mating, days open, service per conception, conception rate, the percentage of repeat breeder animals and pregnancy loss in each group.

\section{Statistical analysis}

At the end of the assay, the data were organized in excel sheets and then parametric variables between three treatments were analyzed using ANOVA test using General Linear Models Procedure (GLM PROC) by SAS (ver: 9.1/ 2005) software. Differences between treatments were tested for significance using the Duncan's Multiple Range test. A P value $<0.05$ was considered significant. For non-parametric variables (conception rate and repeat breeder), 
NONPAR1WAY Procedure was used to compare treatments with Kruskal-Wallis tests.

\section{Results}

There were no significant differences between the treatment groups in the distribution of parity and milk yield. The total number of the cows enrolled in the present study was 138. Eighteen cows were excluded from the study for noted reasons. Therefore, 120 cows remained available for data analysis. Data were obtained for 40 cows in PG-14 group, 40 cows in PG28 group and 40 cows in PG-42 group.

Treatment with PGF2a starting on day 14 postpartum significantly reduced the postpartum interval to first estrus and the number of services per conception (Table 1). Also intervals to first mating and days open were significantly reduced in the cows of the PG-14 group by $\sim 10$ days and $\sim 18$ days, respectively (Table 1). The prevalence of repeat breeder syndrome was not affected with treatment but it tended to be affected by PG-14 (10\% vs. $15 \%$ and $17.5 \%, \mathrm{P}=0.09$, PG-14, PG-28 and PG-42, respectively). No pregnancy loss was detected in the experimental groups (Table 2); therefore, pregnancy rates in each group were identical on days 32 and 62 after mating. Conception rate in PG-14 group was 12.5 and 10 incremented compared to PG-28 and PG-42 groups, respectively (P $=0.01 ;$ Table 2 ).

Table 1 - Effect of different regimens of treatment with prostaglandin F2a during postpartum injection on reproductive performance in three experiments - Semnan, Iran - 2015

\begin{tabular}{|c|c|c|c|c|c|c|c|c|}
\hline \multirow[b]{3}{*}{ Reproductive Parameters } & \multicolumn{6}{|c|}{ Treatments } & \multirow{3}{*}{$P$} & \multirow{3}{*}{ sig } \\
\hline & \multicolumn{2}{|c|}{ PG-14 $(n=40)$} & \multicolumn{2}{|c|}{ PG-28 $(n=40)$} & \multicolumn{2}{|c|}{$P G-42^{3}(n=40)$} & & \\
\hline & Mean $\pm \mathrm{SE}^{4}$ & $\mathrm{CV}$ & Mean \pm SE & CV & Mean \pm SE & CV & & \\
\hline Days to $1^{\text {st }}$ estrus & $34.9^{a} \pm 0.74$ & 13 & $37.35^{b} \pm 0.70$ & 11 & $38.75^{b} \pm 0.89$ & 14 & 0.003 & * \\
\hline Days to $1^{\text {st }}$ mating & $62.35^{\mathrm{a}} \pm 1.53$ & 15 & $72.33^{b} \pm 3.69$ & 21 & $71.28^{\mathrm{b}} \pm 3.32$ & 29 & 0.04 & * \\
\hline Days Open & $117.23^{a} \pm 3.1$ & 16 & $134.63^{b} \pm 2.37$ & 10 & $137.93^{b} \pm 3.24$ & 14 & $<0.001$ & ** \\
\hline Service per conception & $1.9^{a} \pm 0.09$ & 23 & $2.5^{\mathrm{b}} \pm 0.14$ & 30 & $2.35^{\mathrm{b}} \pm 0.02$ & 24 & 0.02 & * \\
\hline
\end{tabular}

${ }_{1}^{1}$ Prostaglandin F2a treatment was started from d 14 postpartum. ${ }^{2}$ Prostaglandin F2a treatment was started from d 28 postpartum. ${ }^{3}$ There was no treatment during voluntary waiting period (first 42 days postpartum). ${ }^{4}$ Standard Error. ${ }^{a, b}$ Values within a row with different superscripts are different $(P<0.05) .{ }^{*}(P<0.05),{ }^{* *}(P<0.001)$

Table 2 - Effect of three experiments on conception rate, pregnancy loss and repeat breeder - Semnan, Iran $-2015$

\begin{tabular}{lccc}
\hline \multicolumn{1}{c}{ Items } & \multicolumn{3}{c}{ Treatments } \\
\cline { 2 - 4 } & $\mathrm{PG}-14^{1}(\mathrm{n}=40)$ & $\mathrm{PG}-28^{2}(\mathrm{n}=40)$ & $\mathrm{PG}-42^{3}(\mathrm{n}=40)$ \\
\hline Pregnancy/mating at 32 \pm 3 d of mating & $52.5 \%(21 / 40)^{\mathrm{a}}$ & $40 \%(16 / 40)^{\mathrm{b}}$ & $42.5 \%(17 / 40)^{\mathrm{b}}$ \\
Pregnancy/mating at $62 \pm 3$ d of mating & $52.5 \%(21 / 40)^{\mathrm{a}}$ & $40 \%(16 / 40)^{\mathrm{b}}$ & $42.5 \%(17 / 40)^{\mathrm{b}}$ \\
Pregnancy loss & $0 \%(0 / 21)^{\mathrm{a}}$ & $0 \%(0 / 16)^{\mathrm{a}}$ & $0 \%(0 / 17)^{\mathrm{a}}$ \\
Repeat breeder & $10 \%(4 / 40)^{\mathrm{a}^{*}}$ & $15 \%(6 / 40)^{\mathrm{a}^{*}}$ & $17.5 \%(7 / 40)^{\mathrm{a}^{*}}$ \\
\hline${ }^{1}$ Prostaglandin F2a treatment was started from d 14 postpartum. ${ }^{2}$ Prostaglandin F2a treatment was started \\
from d 28 postpartum. ${ }^{3}$ There was no treatment during 42 days of voluntary waiting period. ${ }^{\mathrm{a}, \mathrm{b}}$ Values within \\
a row with different superscript letters are significantly different $(\mathrm{P}<0.01) .{ }^{*}$ Values within a row with \\
different superscript letters tended to be significant different $(0.05>\mathrm{P}<0.1)$
\end{tabular}

\section{Discussion}

The objective of this study was to evaluate the effects of immediate postpartum PGF2 $\alpha$ treatment on reproductive performance in dairy cows synchronized with targeted breeding program and naturally mated after VWP. In the present study, treatment with PGF2 $\alpha$ from day 14 postpartum has shown beneficial effects in cows naturally mating.
The rationale for using PGF2 $\alpha$ in the absence of a CL (days 14 postpartum) in our study was based on the results of previous research suggesting that PGF2 $\alpha$ has direct effects on the uterus (LINDELL; KINDAHL, 1983; RISCO et al., 1994), and can resolve uterine infections in cows without a CL (DEL VECCHIO et al., 1994). It has been shown that exogenously administered PGF2a can increase uterine PGF2 $\alpha$ and 
luteal leukotriene B4 (LTB4) secretion (HOEDEMAKER et al., 1992), and that LTB4 can enhance chemotaxis and antibody-independent cellmediated cytotoxicity. It has been reported that PGF2 $\alpha$ promotes uterine involution and reduces the risk of uterine infection (SLAMA et al., 1993). Collectively, this information suggested that exogenous PGF2 $\alpha$ could have beneficial effects on the postpartum uterus in the absence of a CL. Further, it was considered that administration of PGF2 $\alpha$ after the development of a CL would lead to luteolysis, remove the suppressive effect of progesterone on the uterus, enhance uterine defenses and mitigate the immunosuppressive effects of progesterone (LEWIS, 2004).

In the present study, earlier postpartum PGF2 $\alpha$ treatment (day 14; PG-14 group) affected the moment of first estrus and first mating. However, PGF2 $\alpha$ treatment after day 28 postpartum (PG-28 and PG-42) did not affect these parameters. Longer duration and greater magnitude of postpartum peripheral plasma 13,14-dihydro-15-keto-prostaglandin F-metabolite (PGFM) concentrations have been related to faster uterine involution (LINDELL et al., 1982) and may favor earlier resumption of ovarian activity; and Lindell et al. (1982) speculated that uterine synthesis of PGF2a increases uterine muscle tone, promoting uterine involution and, also, that delayed involution is associated with inadequate synthesis of PGF2a. It seems that earlier first estrus and first mating after PGF2 $\alpha$ treatment in PG-14 group was probably due to direct effect of PGF2 $\alpha$ on the uterus, and resolving of uterine infection in cows without a CL in early postpartum. Results from this experiment support previous findings that a single intramuscular injection of PGF2 $\alpha$ in the early postpartum period (between 7 and 28 days) reduced the postpartum interval to conception (YOUNG et al., 1984; BENMRAD; STEVENSON, 1986) and had a positive effect on reproductive performance (WHITE; DOBSON, 1990; PANKOWSKI et al., 1995; NAKAO et al., 1997; SCHOFIELD et al., 1999). These studies did not compare the effect of earlier PGF2 $\alpha$ injection (around day 14 of VWP) and late PGF2a injection (around day 28 of VWP) in VWP but our results showed that earlier PGF2 $\alpha$ treatment was better than late PGF2 $\alpha$ treatment. The shorter postpartum interval to PGF2 $\alpha$ administration was associated with an earlier first postpartum estrus. However, Hendricks et al. (2006) demonstrated that repeated administration of PGF2 $\alpha$ on days 7, 14, 22 and 35 in the early postpartum period had no effect on days to first service and the probability of pregnancy at first insemination. Also, Salasel and Mokhtari (2011) reported that treatment with PGF2 $\alpha$ had no effect on days to first estrus and days to first artificial insemination at day 20 postpartum (SALASEL; MOKHTARI, 2011). Kindahl et al. (1976) and McClary et al. (1989) found that the time to first ovulation was unaffected by PGF2 $\alpha$ treatment, and Young et al. (1984) reported no effect on the postpartum interval to first service. Kasimanickam et al. (2005) reported that PGF2a treatment of cows with subclinical endometritis at 20 to 33 days postpartum did not reduce the median days to first service (KASIMANICKAM et al., 2005). In this regard, unlike our results that achieved from normal postpartum dairy cows, Kasimanickam et al. (2005) reported that there was no benefit in a routine injection of PGF2 $\alpha$ to dairy cows with abnormal puerperium in the period 14 to 28 days after calving when rebreeding commenced more than 70 days after calving (GLANVILL; DOBSON, 1991). It is speculated that the different VWP had influenced the time to first artificial insemination in different studies and can be a reason for different results. It seems that in the case of prolonged VWP, such parameters should not be considered while evaluating the use of PGF2 $\alpha$ in the early postpartum period. Treatment with PGF2 $\alpha$ also affects days to first estrus and mating due to its direct ecbolic effect on the uterus, and positive effect on uterine muscle tone and involution rate (LINDELL; KINDAHL, 1983).

The interval from parturition to involution of the uterus has been reported as lasting from 26 to 52 days 
(MORROW et al., 1969). The length of this interval increases with parity, decreases with an increase in milk production (BUCH et al., 1955). Cows in this experiment were paired for milk yield and parity to minimize these confounding effects. Therefore, it is speculated that days to first estrus and days to first mating are influenced by parity and milk production, which is not similar in all studies.

Our study showed that pregnancy/mating rate on day 32 was improved with PGF2 $\alpha$ administration on day 14 postpartum. Other studies showed that conception rate was not influenced with PGF2a treatment before VWP (SCHOFIELD et al., 1999). Conversely, Salasel and Mokhtari (2011) reported that conception rate and pregnancy loss were improved with administration of PGF $2 \alpha$ on day 21 postpartum.

In the present study, postpartum treatment with PGF2 $\alpha$ from day 14 decreased the mean of days open. Salasel and Mokhtari (2011) showed that days open was decreased (32days) with using PGF2 $\alpha$ in day 21 postpartum. However, Schofield et al. (1999) indirectly demonstrated that treatment with PGF2 $\alpha$ in early postpartum decreases days open. They reported that treatment of dairy cows with PGF2 $\alpha$ at day 21 postpartum reduced the postpartum interval to first service by seven to nine days; therefore, days open was also affected. On the other hand, another study reported that interval to first postpartum insemination of treated cows with PGF2 $\alpha$ was like control group (without PG2 $\alpha$ treatment in early postpartum) and within a range of 130-134 days postpartum (HENDRICKS et al., 2006). Our result showing improvement of days open may have been mediated through a direct action of PGF2 $\alpha$ on uterine smooth muscle causing myometrial contractions of the uterus, in addition to the apparent advancement of ovulation. This may enhance uterine involution as well as cleaning the uterine lumen of residual products resulting from parturition, or subsequently established uterine pathogens.

In this study, mean service per conception in PG14 group was lower than PG-28 and PG-42 groups (1.9 vs. 2.5 and 2.35 , respectively). It is speculated that reduced number of services per conception was the outcome of frequency of estrous cycles before first mating. Other study similarly shown that the mean services per conception were improved (1.64 vs. 2.33) by postpartum treatment with PGF2 $\alpha$ on Days 14 to 16 (MCCLARY et al., 1989). Salasel and Mokhtari (2011) also reported that postpartum treatment with PGF2 $\alpha$ improved the mean service per conception in cows with calving and puerperal traits. Benmard and Stevenson (1986) showed that administration of PGF2 $\alpha$ at 20 to 24 days postpartum reduced services per conception by $26 \%$ to $41 \%$, especially in cows with puerperal problems (BENMARD; STEVENSON, 1986).

According to the results obtained in the current study, injections of PGF2 $\alpha$ on day 14 postpartum reduced the prevalence of repeat breeder syndrome. In agreement with our results, two injections of PGF $2 \alpha 8$ $\mathrm{h}$ apart on day 20 postpartum reduced the prevalence of repeat breeder syndrome in cows with calving and puerperal traits (SALASEL; MOKHTARI, 2011). However, there are some differences in studies which have investigated the use of PGF $2 \alpha$ at the postpartum period in dairy cows and there is difference between day of PGF2 $\alpha$ injection in studies and different studied did not compare effect of early or late PGF2a injection in VWP on reproductive performance. Also, the type of PGF2 $\alpha$ used in these studies, type of animals selected for these studies, protocols used for and the timing of treatment were different. Therefore, some authors reported that PGF2 $\alpha$ treatment in postpartum period had no beneficial effect on fertility (ARCHBALD et al., 1990; GLANVILL, DOBSON, 1991; HENDRICKS et al., 2006), but others showed that it improved reproductive performance (YOUNG et al., 1984; MELENDEZ et al., 2004; KASIMANICKAM et al., 2005). Therefore, the difference in the results of these studies is somewhat due to different study designs. According to above mentioned dissimilarities, it is suggested that further consideration should be given to selection and timing 
of optimum PGF2 $\alpha$ treatment protocol for cows with different kinds of abnormalities in the postpartum period.

In conclusion, despite the cost, the administration of PGF2 $\alpha$ in the immediate postpartum period improves reproductive performance in dairy cows submitted to target breeding program, only when PGF2 $\alpha$ treatments starts earlier on day 14 postpartum compared to days 28 or 42 .

\section{References}

ARCHBALD, L. F.; TRAN, T.; THOMAS, P. G. A.; LYLE, S. K. Apparent failure of prostaglandin $F_{2 \alpha}$ to improve the reproductive efficiency of postpartum dairy cows that had experienced dystocia and/or retained fetal membranes. Theriogenology, v. 34, n. 6, p. 1025-1034, 1990. doi: 10.1016/S0093-691X(05)80001-9.

BENMRAD, M.; STEVENSON, J. S. Gonadotropinreleasing hormone and prostaglandin $\mathrm{F}_{2 \alpha}$ for postpartum dairy cows: estrous, ovulation, and fertility traits. Journal of Dairy Science, v. 69, n. 3, p. 800-811, 1986. doi: 10.3168/jds.S0022-0302(86)80469-6.

BONNETT, B. N.; ETHERINGTON, W. G.; MARTIN, S. W.; JOHNSON, W. H. The effect of prostaglandin administration to Holstein-Friesian cows at Day 26 postpartum on clinical findings, and histological and bacteriological results of endometrial biopsies at Day 40 . Theriogenology, v. 33, n. 4, p. 877-890, 1990. doi: 10.1016/0093-691X(90)90823-C.

BUCH, N.; TYLER, W. J.; CASIDA, L. E. Postpartum estrus and involution of the uterus in an experimental herd of Holstein-Friesian cows. Journal of Dairy Science, v. 38, n. 1, p. 73-79, 1955. doi: 10.3168/jds.S0022-0302(55)94940-7.

DEJARNETT, M. Ovsynch, co-sunch, presynch and kitchensynch: how did breeding cows get so complicated? Select Sires, p. 1-6, 2015.

DEL VECCHIO, R. P.; MATSAS, D. J.; FORTIN, S.; SPONENBERG, D. P.; LEWIS, G. S. Spontaneous uterine infections are associated with elevated prostaglandin $F_{2 \alpha}$ metabolite concentrations in postpartum dairy cows. Theriogenology, v. 41, n. 2, p. 413-421, 1994. doi: 10.1016/0093-691X(94)90077-V.

\section{Conflict of interest}

The authors declare that there is no conflict of interest.

\section{Acknowledgment}

The authors thank Mr. Norani for use of the dairy herd.

EDQVIST, L. E.; KINDAHL, H.; STABENFELDT, G. Release of prostaglandin $F_{2 \alpha}$ during the bovine peripartal period. Prostaglandins, v. 16, n. 1, p. 111-119, 1978. doi: 10.1016/0090-6980(78)90207-1.

ETHERINGTON, W. G.; MARTIN, S. W.; BONNETT, B.; JOHNSON, W. H.; MILLER, R. B.; SAVAGE, N. C.; WALTON, J. S.; MONTGOMERY, M. E. Reproductive performance of dairy cows following treatment with cloprostenol 26 and/or 40 days postpartum: a field trial. Theriogenology, v. 29, n. 3, p. 565-575, 1988. doi: 10.1016/S0093-691X(88)80005-0.

GLANVILL, S.; DOBSON, H. Effect of prostaglandin treatment on the fertility of problem cows. Veterinary Record, v. 128, n. 16, p. 374-376, 1991. doi: $10.1136 / v r .128 .16 .374$.

GUILBAULT, L. A.; THATCHER, W. W.; FOSTER, D. B.; CATON, D. Relationship of 15-keto-13, 14-dihydroprostaglandin $\mathrm{F} 2 \alpha$ concentrations in peripheral plasma with local uterine production of $F$ series prostaglandins and changes in uterine blood flow during the early postpartum period of cattle. Biology of Reproduction, v. 31, n. 5, p. 870-878, 1984. doi: 10.1095/biolreprod31.5.870.

HENDRICKS, K. E. M.; BARTOLOME, J. A.; MELENDEZ, P.; RISCO, C.; ARCHBALD, L. F. Effect of repeated administration of $\mathrm{PGF}_{2 \alpha}$ in the early post partum period on the prevalence of clinical endometritis and probability of pregnancy at first insemination in lactating dairy cows. Theriogenology, v. 65, n. 8, p. 1454-1464, 2006. doi: 10.1016/j.theriogenology.2005.08.018. 
HIRSBRUNNER, G.; KNUTTI, B.; KÜPFER, U.; BURKHARDT, H.; STEINER, A. Effect of prostaglandin $E_{2}$, dl-cloprostenol, and prostaglandin $\mathrm{E}_{2}$ in combination with dcloprostenol on uterine motility during diestrus in experimental cows. Animal Reproduction Science, v. 79, n. 1-2, p. 17-32, 2003. doi: 10.1016/S0378-4320(03)00085-X.

HOEDEMAKER, M.; LUND, L. A.; WAGNER, W. C. Influence of arachidonic acid metabolites and steroids on function of bovine polymorphonuclear neutrophils. American Journal of Veterinary Research, v. 53, n. 9, p. 1534-1539, 1992.

KASIMANICKAM, R.; DUFFIELD, T. F.; FOSTER, R. A.; GARTLEY, C. J.; LESLIE, K. E.; WALTON, J. S.; JOHNSON, W. H. The effect of a single administration of cephapirin or cloprostenol on the reproductive performance of dairy cows with subclinical endometritis. Theriogenology, v. 63, n. 3, p. 818-830, 2005. doi: 10.1016/j.theriogenology.2004.05.002.

KINDAHL, H.; EDQVIST, L. E.; GRANSTRÖM, E.; BANE, A. The release of prostaglandin $F_{2 \alpha}$ as reflected by 15-keto13, 14-dihydroprostaglandin $\mathrm{F}_{2 \alpha}$ in the peripheral circulation during normal luteolysis in heifers. Prostaglandins, v. 11, n. 5, p. 871-878, 1976. doi: 10.1016/0090-6980(76)90194-5.

LEWIS, G. S. Steroidal regulation of uterine immune defenses. Animal Reproduction Science, v. 82-83, p. 281 294, 2004. doi: 10.1016/j.anireprosci.2004.04.026.

LINDELL, J. O.; KINDAHL, H. Exogenous prostaglandin F2alpha promotes uterine involution in the cow. Acta Veterinaria Scandinavica, v. 24, n. 3, p. 269-274, 1983.

LINDELL, J. O.; KINDAHL, H.; JANSSON, L.; EDQVIST, L. E. Postpartum releases of prostaglandin $F_{2 \alpha}$ and uterine involution in the cow. Theriogenology, v. 17, p. 237-245, 1982. doi: 10.1016/0093-691X(82)90085-1.

MCCLARY, D. G.; PUTNAM, M. R.; WRIGHT, J. C.; SARTIN JUNIOR, J. L. Effect of early postpartum treatment with prostaglandin $F_{2 \alpha}$ on subsequent fertility in the dairy cow. Theriogenology, v. 31, n. 3, p. 565-570, 1989. doi: 10.1016/0093-691X(89)90241-0.
MELENDEZ, P.; MCHALE, J.; BARTOLOME, J.; ARCHBALD, L. F.; DONOVAN, G. A. Uterine Involution and Fertility of Holstein Cows Subsequent to Early Postpartum PGF $_{2 \alpha}$ Treatment for Acute Puerperal Metritis. Journal of Dairy Science, v. 87, n. 10, p. 3238-3246, 2004. doi: 10.3168/jds.S0022-0302(04)73460-8.

MORROW, D. A.; TYRRELL, H. F.; TRIMBERGER, G. W. Effects of liberal concentrate feeding on reproduction in dairy cattle. Journal of the American Veterinary Medical Association, v. 155, n. 12, p. 1946-1954, 1969.

MORTIMER, R. G.; BALL, L.; OLSON, J. D.; HUFFMAN, E. M.; FARLN, P. W. The effect of $\mathrm{PGF}_{-2}$ alpha on reproductive performance of naturally bred dairy cows with or without pyometra. Theriogenology, v. 21, n. 6, p. 869-874, 1984. doi: 10.1016/0093-691X(84)90380-7.

NAKAO, T.; GAMAL, A.; OSAWA, T.; NAKADA, K.; MORIYOSHI, M.; KAWATA, K. Postpartum plasma PGF metabolite profile in cows with dystocia and/or retained placenta, and effect of fenprostalene on uterine involution and reproductive performance. Journal of Veterinary Medical Science, v. 59, n. 9, p. 791-794, 1997. doi: 10.1292/jvms.59.791.

PANKOWSKI, J. W.; GALTON, D. M.; ERB, H. N.; GUARD, C. L.; GRÖHN, Y. T. Use of prostaglandin $F_{2 \alpha}$ as a postpartum reproductive management tool for lactating dairy cows. Journal of Dairy Science, v. 78, n. 7, p. 14771488, 1995. doi: 10.3168/jds.S0022-0302(95)76770-4.

PETERS, A. R. Effect of prostaglandin F2 alpha on hormone concentrations in dairy cows after parturition. Veterinary Record, v. 124, n. 14, p. 371-373, 1989. doi: 10.1136/vr.124.14.371.

RISCO, C. A.; ARCHBALD, L. F.; ELLIOTT, J.; TRAN, T.; CHAVATTE, P. Effect of hormonal treatment on fertility in dairy cows with dystocia or retained fetal membranes at parturition. Journal of Dairy Science, v. 77, n. 9, p. 25622569, 1994. doi: 10.3168/jds.S0022-0302(94)77197-6.

SALASEL, B.; MOKHTARI, A. Effect of early postpartum $\mathrm{PGF}_{2 \alpha}$ treatment on reproductive performance in dairy cows with calving and puerperal traits. Theriogenology, v. 76, n. 9, p. 1723-1729, 2011. doi: 10.1016/j.theriogenology.2011.07.004. 
SCHOFIELD, S. A.; KITWOOD, S. E.; PHILLIPS, C. J. C. The Effects of a post partum injection of prostaglandin $\mathrm{F}_{2 \alpha}$ on return to oestrus and pregnancy rates in dairy cows. The Veterinary Journal, v. 157, n. 2, p. 172-177, 1999. doi: 10.1053/tvjl.1998.0247.

SHELDON, I. M.; WILLIAMS, E. J.; MILLER, A. N.; NASH, D. M.; HERATH, S. Uterine diseases in cattle after parturition. The Veterinary Journal, v. 176, n. 1, p. 115121, 2008. doi: 10.1016/j.tvjl.2007.12.031.

SLAMA, H.; VAILLANCOURT, D.; GOFF, A. K. Leukotriene B4 in cows with normal calving, and in cows with retained fetal membranes and/or uterine subinvolution. Canadian Journal of Veterinary Research, v. 57, n. 4, p. 293-299, 1993.
THATCHER, W. W.; BILBY, T. R.; BARTOLOME, J. A.; SILVESTRE, F.; STAPLES, C. R.; SANTOS, J. E. P. Strategies for improving fertility in the modern dairy cow. Theriogenology, v. 65, n. 1, p. 30-44, 2006. doi: 10.1016/j.theriogenology.2005.10.004.

WHITE, A. J.; DOBSON, H. Effect of prostaglandin F2 alpha on the fertility of dairy cows after calving. Veterinary Record, v. 127 , n. 24 , p. $588-592$, 1990. doi: 10.1136/vr.127.24.588.

YOUNG, I.; ANDERSON, D.; PLENDERLEITH, R. Increased conception rate in dairy cows after early post partum administration of prostaglandin F2 alpha THAM. Veterinary Record, v. 115, n. 17, p. 429-431, 1984. doi: 10.1136/vr.115.17.429. 